\title{
FESTIVAL CONCRETO: grafite e mediação cultural em Fortaleza
}

\section{FESTIVAL CONCRETO: graphite and cultural mediation in Fortaleza}

\author{
Amanda Alcântara da Silva ${ }^{1}$ \\ Jefferson Veras Nunes ${ }^{2}$ \\ Antônio Wagner Chacon Silva ${ }^{3}$
}

\begin{abstract}
${ }^{1}$ Bacharela em Biblioteconomia pela
Universidade Federal do Ceará (UFC).

E-mail: amandaalcantaraufc@gmail.com

${ }^{2}$ Doutor em Ciência da Informação pela Universidade Estadual Paulista Júlio de Mesquita Filho (UNESP). Professor do Departamento de Ciências da Informação da Universidade Federal do Ceará (UFC).
\end{abstract}

\section{E-mail: jefferson.veras@yahoo.com.br}

${ }^{3}$ Doutor em Educação pela Universidade Federal do Ceará (UFC). Professor do Departamento de Ciências da Informação da Universidade Federal do Ceará (UFC).

E-mail: ciberwagner@yahoo.com.br

\section{A ACESSO ABERTO}

Copyright: Esta obra está licenciada com uma Licença Creative Commons Atribuição 4.0 Internacional. $(\mathrm{cc})$ EY

Conflito de interesses: A autora declara que não há conflito de interesses.

Financiamento: Não há.

Declaração de Disponibilidade dos dados: Todos os dados relevantes estão disponíveis neste artigo.

Recebido em: 19/11/2018.

Aceito em: 07/12/2018.

Revisado em: 11/12/2018.

\section{Como citar este artigo:}

SILVA, Amanda Alcântara da; NUNES, Jefferson Veras; SILVA, Antônio Wagner Chacon. Festival Concreto: grafite e mediação cultural em
Fortaleza. Informação em Pauta, Fortaleza, v. 3, n. 2, p. 99-120, jul./dez. 2018. DOI: https://doi.org/10.32810/25253468.ip.v3i2.2018.39647.99-120.

\section{RESUMO}

Trata sobre os grafites do Festival Concreto como agentes de ressignificação urbana e instrumento de mediação cultural. Apresenta um panorama histórico, bem como as características e suportes do grafite. Discute a forma como os grafites do Festival Concreto têm sido utilizados como embelezadores do espaço urbano e instrumento de mediação cultural e informacional. Para isto foi realizada uma pesquisa exploratória de abordagem qualitativa, utilizando-se como método a iconologia com o objetivo de estudar o grafite como informação estética e canal de comunicação. Foram analisados grafites produzidos durante edições do Festival Concreto. Concluiu-se que os grafites idealizados pelo Festival não perderam o seu caráter artístico, que traz beleza e cor para a cidade, no entanto, mais do que isso, são utilizados como canal de comunicação e instrumento de mediação cultural entre homem e cidade.

Palavras-chave: Mediação da informação. Mediação cultural. Grafite. Arte urbana.

\section{ABSTRACT}

It treats on the graphite of Festival Concreto as agents of urban resignification and instrument of cultural mediation. It presents a historical overview as well as the characteristics and supports of graphite. It discusses how the graphite of the Festival Concreto has been used as embellishers of the urban space and instrument of cultural and informational mediation. For this, an exploratory research of 
qualitative approach was carried out, using as iconology method with the objective of studying graphite as aesthetic information and communication channel. The graphites produced during editions of Festival Concreto were analyzed. It was concluded that the graphite idealized by the Festival did not lose their artistic character, which brings beauty and color to the city, nevertheless, more than that, they are used as a channel of communication and instrument of cultural mediation between man and city.

Keywords: Mediation of information. Cultural mediation. Graphite. Urban art.

\section{INTRODUÇÃO}

Nascido sob a influência de uma cultura caracterizada como marginal, o grafite sofreu diversas transformações com o passar dos anos, quando deixou de representar o dia a dia das tribos nas paredes das cavernas, para manifestar amor, ódio e opiniões políticas nos trens e muros da cidade, chegando às galerias de arte e sendo produzidos, inclusive, por artistas renomados.

Atualmente, o grafite possui o status de arte democrática, pois possibilita tanto um embelezamento da urbe, como, também, é passível de suscitar, através das imagens e textos que produz, reflexões sobre os modos de vida urbanos.

Dessa maneira, seja nas cavernas, nos trens, nos muros ou até mesmo nas galerias de arte, o grafite se apresenta como um produto social, que é resultado, na maioria das vezes, das vivências do próprio artista que o concebe a partir de sua relação com a sociedade de determinada época.

Nesse sentido, apresentar o grafite enquanto um produto social que se traduz também em canal de comunicação e meio de expressão é defender a necessidade constante de criação de novos campos de estudo na Ciência da Informação (CI), uma vez que, segundo Albuquerque (2004), o objeto do estudo da área costuma recair “[...] sobre pontos há muito delimitados pelos rigores acadêmicos que oficializam as temáticas tradicionais em detrimento das alternativas". Quer dizer, é romper com vieses não só consolidados, mas hegemônicos, que ambicionam reforçar as mesmas perspectivas de se estudar a informação no âmbito da CI.

A escolha do tema deste artigo foi incitada pela admiração da obra de um importante ativista do grafite contemporâneo - o britânico Banksy. Seja através de sua arte ou por meio de seus livros e documentários, percebe-se a aversão de Banksy aos conceitos de permanência, autoridade, poder e indústria cultural, dentre outros, 
contestando, inclusive, a própria mercantilização da arte. Portanto, a partir do apreço pelo trabalho de Banksy, especialmente pela forma com a qual o artista alia humor e crítica, que as paisagens da cidade passaram a chamar cada vez mais a atenção dos autores deste artigo.

O Festival Concreto, evento que ocorre em Fortaleza desde 2013, foi escolhido como objeto de análise pela sua relevância no contexto da arte urbana, justamente por tratar-se do primeiro evento internacional desse tipo de manifestação artística realizado na região Nordeste, que reúne artistas de diferentes países. Recorrendo a instalações e pinturas, o festival atua promovendo intervenções em vários bairros, marcando presença em muros e prédios da orla marítima, do centro e das periferias, num convite à ocupação e ressignificação da cidade.

Assim, a presente pesquisa tem como princípio norteador a seguinte questão: de que maneira os grafites produzidos durante o Festival Concreto podem ser tomados enquanto artefatos de mediação cultural acerca do cotidiano da cidade de Fortaleza? Com base nesse questionamento, estabelece-se como objetivo analisar o potencial do grafite enquanto elemento cultural de mediação entre homem e cidade, tomando como objeto o Festival Concreto e como locus a cidade de Fortaleza.

\section{MEDIAÇÃO E CULTURA}

O conceito de mediação tem sido bastante discutido no campo da Ciência da Informação nos últimos anos, especialmente por conta de seu potencial heurístico, como demonstram Nunes e Cavalcante (2017, online), ao afirmarem que "a mediação se situa naqueles quadros da Ciência da Informação (CI) que defendem, em primeiro lugar, uma natureza interdisciplinar para a área [...]”, possibilitando, assim, “[...] uma abordagem sociocultural de seu objeto, considerando os diversos contextos nos quais os indivíduos estão inseridos como algo imprescindível ao estudo da informação".

Nunes e Cavalcante (2017, online) defendem a ideia de que é possível apontar a existência de uma "epistéme mediacional" na CI, em virtude da "[...] composição de um paradigma cada vez mais voltado aos estudos da mediação, especialmente no modo como a área tem se configurado no Brasil". Esse paradigma também reforça a discussão em prol de uma estruturação da área fortemente sustentada no âmbito das Ciências Sociais e Humanas. 
Contudo, antes da emergência de uma "epistéme mediacional", Almeida Junior (2009, p. 92-93), em suas pesquisas, já criticava o fato do conceito de mediação ser, por vezes, considerado como desnecessário nas discussões da CI, justamente porque era comum partir-se da ideia de que este seria intuitivamente assimilado, o que dispensaria aprofundamentos teóricos no debate em torno dele. De acordo com o autor, "o senso comum dos profissionais da área identifica a mediação da informação com a imagem de uma ponte. Esta, como aquela, permite a relação entre dois pontos que, de alguma forma, estão impedidos de interagir por obstáculos e empecilhos". Nesse sentido, o mesmo autor considera que a concepção de ponte não é apropriada para o conceito de mediação, pois apresenta a idealização de algo estático onde não há interferências externas.

Para o autor, o conceito de mediação da informação se apresenta como:

Toda ação de interferência - realizada pelo profissional da informação -, direta ou indireta; consciente ou inconsciente; singular ou plural; individual ou coletiva; que propicia a apropriação de informação que satisfaça, plena ou parcialmente, uma necessidade informacional [...] tal mediação passa a se constituir não como coadjuvante no âmbito da CI, mas interferindo em seu próprio objeto (ALMEIDA JUNIOR, 2009, p. 92).

É importante ressaltar que a mediação vai além do processo de comunicação entre emissor e receptor, pois se distancia de uma relação linear entre oferta e recepção, uma vez que essa ideia negligencia a complexidade no processo de apropriação da informação e das transformações que ela pode acarretar à vida das pessoas (FEITOSA, 2016). De acordo com Feitosa (2016), a expressão mediação da informação alude principalmente à necessidade de se esquadrinhar epistemologicamente o conceito, de modo a evitar render-se ao perigo que é a sua compreensão enquanto algo estritamente relacionado à informação, “[...] como se mediação não fosse ela mesma um fenômeno gregário da cultura" (FEITOSA, 2016, p. 103).

Isso sugere que a informação é reflexo da cultura, a qual pode atuar diretamente na sua formação, produção e disseminação, ou seja, a informação está relacionada à cultura, depende dela, sendo ambas capazes de expressar, em alguma quantidade e qualidade, a dinâmica da sociedade. Muito se discute sobre cultura, apesar de não haver uma definição consensual para o termo. Na perspectiva de Laraia (2001), cultura pode ser entendida como a necessidade que o homem tem de atribuir sentido ao desconhecido. Concordando com essa ideia, segundo afirma Feitosa (2016, p. 5), “[...] 
cultura é o processo através do qual o homem cria o algo onde antes imperava o nada. Esse algo é toda complexidade de criações simbólicas, de sentidos e significados que damos às coisas e ao mundo". Percebe-se, assim, que, cultura está atrelada à construção de sentidos pelo homem, constituindo-se parte imanente do próprio processo de mediação.

Em complemento à definição de Laraia, cabe evocar Santos (1996), que propõe duas concepções básicas de cultura. São elas:

\begin{abstract}
A primeira dessas concepções preocupa-se com todos os aspectos de uma realidade social. Assim, cultura diz respeito a tudo aquilo que caracteriza a existência social de um povo ou nação [...] na segunda quando falamos em cultura estamos nos referindo mais especificamente ao conhecimento, às ideias e crenças assim como a maneira que eles existem na vida social (SANTOS, 1996, p. 24-25).
\end{abstract}

As duas concepções se referem à realidade social de um povo e é o entendimento dela que alimenta a visão por meio da qual a cultura é não só percebida, mas, ainda, sentida, o que possibilita a sua propagação na sociedade através das interações sociais. De modo geral, tal ideia, em alguma quantidade ou qualidade, alude ao próprio processo de mediação, que, conforme Feitosa (2016, p. 5), é, “[...] por excelência, cultural”.

Na discussão sobre mediação pode-se encontrar também a expressão mediação cultural, frequentemente adotada para aludir a:

[...] Um campo amplo, no qual se inserem instituições como bibliotecas, museus e teatros, além de uma rica variedade de espaços que venham a fomentar ações no âmbito da cultura, visando proporcionar uma aproximação dos públicos com obras de arte, livros, peças teatrais, exposições, espetáculos e demais atividades reconhecidas como sendo de caráter cultural (NUNES; CAVALCANTE, online).

Ao ser entendida dessa forma, a mediação remete à composição de um locus no qual há o contágio entre "[...] as esferas da produção e da recepção dos signos" (PERROTI, 2016, p. 09). Nesse sentido, Davallon (2007, p. 4) define mediação cultural como algo que visa levar um público a um produto artístico-cultural e a sua atuação funda-se em engendrar um campo de interação entre os universos do público e o do artefato cultural, com o intuito de viabilizar uma apropriação deste por aquele. Seu objetivo principal é oferecer entendimento sobre algo, facilitando a interação e a apreensão do objeto por parte do público que, por vezes, recepciona e interage com as obras a que tem acesso. 
Nessa perspectiva, pode-se compreender o grafite como manifestação cultural, a qual expressa a arte de grupos tidos como marginalizados e que recorrem à cidade como canal de comunicação e às paredes, muros, trens e placas como suporte para externar sentimentos, opiniões e vivências. Dessa maneira, o grafite explora o espaço público para promover complexas formas de mediação cultural e artística.

No graffiti ocorre, de forma peculiar, o estreitamento das relações entre atividade estética, cidade, política e espaço sob a perspectiva de sujeitos que vivem no próprio contexto da intervenção ou que nele se inserem para inscrever-se no diálogo aberto com a cidade. Através das imagens e dos textos, o graffiti propõe outra relação com o entorno urbano [...] (FURTADO; ZANELLA, 2009, p.1299).

Portanto, tendo a cidade como seu principal suporte, o grafite vem sendo utilizado para construir relações entre o indivíduo e a urbe, sendo ele também fruto das vivências do sujeito que o produz. 0 grafite, segundo Ramos (2007, p. 1267), “é um canal de comunicação, sem conexão com fibra ótica ou cabo elétrico, é conectado diretamente com a cidade, com o público, com o aqui e o agora". Essa manifestação tem o poder de instigar o questionamento das pessoas acerca de seus valores, sobre a ocupação da cidade e seus ideais.

\section{PANORAMA HISTÓRICO DO GRAFITE}

O primeiro passo para entrar no universo artístico e dinâmico do grafite é entender quando e onde ele surgiu. De acordo com Gitahy (1999), a palavra graffiti vêm do italiano graffito, que significa inscrição ou desenhos de épocas passadas riscados em rochas, paredes ou outros espaços. Graffiti é o plural de graffito. No singular, é usada para significar a técnica (pedaço de pintura no muro em claro e escuro); e, no plural, refere-se aos desenhos. No Brasil, o termo ganhou nacionalidade própria, sendo chamado assim por grafite.

0 hábito de fazer desenhos, escrever nomes e frases, manifestar-se artisticamente em diversos lugares acompanha a história da humanidade. Os vestígios mais antigos da passagem do homem pelo planeta estão gravados nas paredes das cavernas e são os primeiros exemplos de grafite que encontramos na história da arte. Nessa época, os materiais usados eram sucos de plantas, ossos fossilizados ou 
calcinados, misturados com água e gordura de animais. Nos dias atuais, os grafiteiros se utilizam de spray, pincéis, tintas e giz, dentre outros materiais. Quanto aos desenhos, já não são expostos cervos e bisões, mas manifestam ideias que configuram a sociedade atual, novas formatações estéticas, sugerindo novos objetivos políticos e aspirações culturais, como ressaltam Furtado e Zanella (2009).

Conforme Gitahy (1999), o muralismo contemporâneo ficou marcado pelos pintores mexicanos Diego Rivera, José Clemente Orozco e David Alfaro Siqueiros, que foram convidados pelo intelectual revolucionário José Vasconcelos a utilizar as técnicas da pintura mural. Em 1905, o pintor Bernardo Carnada (de pseudônimo Dr. AIL) publicou um manifesto onde defendia a necessidade de uma arte pública. Após 15 anos, Siqueiros publicou em Barcelona, um apelo aos artistas da América, proclamando a necessidade de se promover uma arte capaz de falar ao povo.

O costume se popularizou no mundo inteiro e, com o tempo, a técnica que recebeu o nome de pichação, graças ao picho - material que era utilizado para escrita nas paredes desde a Antiguidade -, passou a ser usada como forma de protesto. Depois da Segunda Guerra Mundial e do grande avanço tecnológico que ela trouxe, iniciou-se a fabricação de materiais em aerossol. Gitahy (1999) salienta que o uso do spray começou a substituir as técnicas anteriores, proporcionando maior liberdade de movimentos e maior rapidez, essenciais para uma prática ilegal à época.

Por ser considerada ilegal e subversiva, a atividade da pichação era executada sempre à noite. Mesmo assim, essa prática foi se popularizando e perdendo seu exclusivo caráter político. As pichações já não pediam somente a cabeça desse ou daquele governante, mas declaravam amor, faziam piadas ou simplesmente exibiam o nome de seus autores (GITAHY, 1999, p. 21).

Tanto o grafite como a pichação usam o mesmo suporte - a cidade - e o mesmo material (tintas). Assim como o grafite, a pichação interfere no espaço, subverte valores, e é espontânea, gratuita e efêmera. Uma das diferenças entre o grafite e a pichação é que o primeiro advém das artes plásticas e o segundo da escrita, ou seja, o grafite privilegia a imagem: a pichação, a palavra e/ou letra. (GITAHY,1999, p.19).

Apesar de tamanhas semelhanças, é bastante comum enxergar uma associação entre ambos, mas de uma forma antagônica, as pessoas colocam o grafite e a pichação como rivais, sendo o grafite tido como uma manifestação artística e a pichação caracterizada como crime. Conforme Ramos (2007, p. 1260), “ainda que essas 
intervenções sejam transgressoras e semelhantes, os grafites e pichações apresentam técnicas e políticas diferenciadas de acordo com o propósito de cada agente ou grupo em seu tempo e espaço definidos".

Ainda segundo Ramos (2007), a cidade de Nova Iorque foi tomada pelos desenhos, frases e caligrafias elaboradas que passaram a circular nos trens subterrâneos. Os grafites eram concebidos por pessoas de diferentes classes sociais e das mais variadas nacionalidades, que iam de chineses, ucranianos, filipinos, dominicanos, jamaicanos e nigerianos, sendo, a maioria, do sexo masculino e pertencente à categoria etária da juventude.

O movimento que ganhou espaço nos trens da cidade surpreendeu a população; e não satisfeitos em escrever seus nomes e desenhar imagens, os writers passaram a escrever mensagens com suas assinaturas e percebendo a possibilidade de comunicação através do grafite, começaram a ocupar espaços na cidade (RAMOS, 2007). Pseudônimos, siglas, números invadiram os corredores de tráfico intenso.

O Muro de Berlim - também conhecido como "Muro da vergonha" - é, de acordo com Ramos (2007), um dos espaços mais polêmicos quando se trata sobre o grafite na contemporaneidade. Esse muro foi construído em 1961 no intuito de proibir as fugas das pessoas que tentavam cruzar do Leste para o Oeste, em decorrência da divisão do território alemão, após a Segunda Guerra Mundial, entre os Estados Unidos, o Reino Unido, a França e a União Soviética. O muro simbolizava a bipolarização do mundo e demarcava os limites territoriais dos regimes socialista e capitalista. Do lado Leste, o muro só mostrava cor nos incidentes de sangue; por sua vez, do lado Oeste, foi somente depois de 15 anos que o muro começou a ganhar cores nas mais diversas manifestações e apelos por sua derrubada.

O muro foi fisicamente derrubado em 1989, no entanto, a queda não significou o seu fim. Muitas imagens dos grafites foram registradas em fotos e permanecem como testemunha da história, compondo parte do patrimônio artístico de museus de arte espalhados pelo mundo. Pode-se dizer que a partir daí se deu o boom do grafite na forma como ele é atualmente conhecido nas metrópoles.

Em Berlim, no entanto, ainda conserva-se parte do muro, num trecho que mede pouco mais de $1 \mathrm{~km}$, sendo conhecido como East Side Gallery. Além de ser uma das maiores galerias de arte ao ar livre, tal trecho abriga grafites de artistas de diferentes 
lugares do mundo, tendo como principal motivo, em várias das imagens, as mudanças ocasionadas com o fim da divisão.

No Brasil, aponta-se que a popularização do grafite se deu por causa da insatisfação de jovens com as políticas impostas à cidade e à arte nos anos 1980. Além disso, com o intuito de lutar pela redemocratização do País, em tempos de Diretas Já, Ramos (2007) afirma que significativas intervenções com grafites começaram a ser realizadas no campus universitário da USP, nas margens do rio Tietê e no Túnel Rebouças.

É possível assinalar ainda que a ascensão do grafite no Brasil esteve diretamente ligada ao movimento hip-hop, e segundo Rodrigues e Bessa (2015), no caso de Fortaleza também não foi diferente. Embora, atualmente, o grafite não esteja mais restrito à influência do movimento hip-hop, segundo as autoras, com o passar dos anos, foi ganhando novos sentidos, temáticas e práticas. Os grafites pioneiros na cidade eram, inicialmente, facilmente confundidos com pichações, pois durante muito tempo o termo grafite era utilizado para denominar todos os rabiscos nos muros da cidade.

Os primeiros grupos a se lançarem no movimento, segundo Pereira (2012), foram os coletivos 'Grafiticidade' e 'Acidum'. A trajetória do Grafiticidade começou em 2002, de acordo com Rodrigues e Bessa (2015), a partir de um projeto pautado em arte e educação, promovido pela Prefeitura de Fortaleza, onde eram oferecidas oficinas sobre a arte do grafite, especialmente nos bairros Centro e Benfica. Já o Acidum foi formado, segundo Pereira (2012), por ex-alunos dos cursos de Artes do Instituto Federal de Educação, Ciência e Tecnologia e por ex-bolsistas do Centro Dragão do Mar de Arte e Cultura, em Fortaleza.

No que parece ser o lado oposto das técnicas empregadas pelos artistas plásticos, estavam os grupos como o 'Viciados em Tinta Spray' (VTS) e o 'Revolução Através dos Muros' (RAM) que acreditavam que o grafite era, antes de tudo, um instrumento de protesto, que quanto mais próximo das artes plásticas, mais longe da cultura da periferia. (RODRIGUES; BESSA, 2015).

Apesar do campo de tensões estabelecido pela rivalidade dos coletivos, o grafite continuou em expansão até se tornar palco de um festival de arte urbana que serviu não apenas como celebração de talentos locais, mas possibilitou o intercâmbio de saberes de grandes artistas do grafite mundial. 


\title{
3.1 Sobre o festival
}

Em 2013 foi promovido em Fortaleza o primeiro grande encontro para se discutir sobre arte urbana: o Festival Concreto. Idealizado e organizado pelo artista Narcélio Grud, o evento proporcionou um intercâmbio cultural de arte urbana entre artistas e a população da cidade. Dentre as atividades desenvolvidas pelo Festival, vale citar a realização de várias “[...] exposições, intervenções, workshops, oficinas e palestras, técnicas e linguagens, como o muralismo, o grafite, a música e a dança. Fazendo uso da cidade como principal suporte" (FESTIVAL CONCRETO)i.

Depois dessa primeira edição, já aconteceram mais quatro edições nos anos de 2015, 2016, 2017 e 2018. A arte urbana, de maneira geral, possui uma grande importância na construção da memória coletiva, seja através de mensagens de cunho político, com um tom de resistência, ou com murais e pinturas que visam o desenvolvimento artístico e estético.

Assim, pode-se dizer que a história da arte urbana em Fortaleza confunde-se com a própria história da cidade, desde os murais produzidos por Chico da Silva, até as esculturas modeladas por Sérvulo Esmeraldo.

\begin{abstract}
Dos murais feitos a carvão pelo artista Chico da Silva nas ruas do Pirambu, às esculturas públicas de Sérvulo Esmeraldo presentes por toda cidade, podemos perceber as marcas de uma época. Com caráter efêmero ou não, muitos foram os artistas que levaram para as ruas seus trabalhos nas últimas décadas e marcaram gerações. Nos dias de hoje, ainda podemos encontrar obras públicas de Zenon Barreto, Leonilson, Ademir Martins, Estrigas, para citar alguns das gerações que já se foram, mas que continuam com suas obras presentes na cidade de Fortaleza. (FESTIVAL CONCRETO)ii.
\end{abstract}

A arte urbana chegou a Fortaleza na década de 1990, trazendo consigo seu caráter transgressor através das pichações. No decorrer dos anos 2000, após surgimento de novos materiais, conceitos e termos sobre a arte urbana, indivíduos e grupos artísticos passaram a apropriar-se dessas manifestações de ordem estética como meio de adornar espaços, não somente embelezando, mas, também, atribuindo novos significados a determinados pontos da cidade.

Com o advento das tecnologias de informação e comunicação, a propagação de artistas e técnicas que fazem dos muros, postes, semáforos, prédios e lixeiras, suporte para divulgação de sua arte, ganhou novas proporções, adquirindo, principalmente, maior expressividade. 
Para Grud, criador do Festival Concreto,

A simples ação de inscrever meu nome nas paredes da cidade serviu de porta por onde adentrei ao universo da arte urbana, me encontrei e após tempos de labuta participei de alguns festivais em diversas cidades de diferentes países, lugares onde pude fazer amigos, sentir e vivenciar inúmeras vezes a energia empolgante de transformação que esses eventos propiciam. Surgiu daí o desejo de fazer algo parecido na cidade onde vivo. A cidade de Fortaleza sofre com a grande desigualdade social e a violência, sendo, assim, um ambiente propício e necessitado de ações dessa naturezaiii.

O Festival surge, assim, com a ideia de transformar o olhar do homem urbanus sobre a sua própria cidade, engendrando um canal por meio do qual a população possa se dar conta, sob uma perspectiva sensível, das diferenças e desigualdades sociais, do modo de vida contemporâneo, dos acontecimentos cotidianos, de fatos políticos, podendo tocar ainda em várias outras questões que sejam de interesse do artista.

\section{PROCEDIMENTOS METODOLÓGICOS}

A pesquisa teve caráter exploratório e recorreu à abordagem qualitativa que, para Minayo (2001), lida com o universo de significados, motivações, crenças e valores, voltando-se ao estudo de um universo que não pode ser quantificado, correspondendo ao espaço mais profundo das relações, dos processos e dos fenômenos. Na pesquisa qualitativa há um aprofundamento da compreensão de um fenômeno a partir de um ponto de vista social.

Para proceder a análise dos dados, adotou-se o método da iconologia, que, de acordo com Vicente (2014), referindo-se ao trabalho de Panofsky, permite ao pesquisador realizar observações com maior acuidade sobre uma imagem do que as análises feitas pela iconografia, inicialmente, tratando tanto do conteúdo, como do significado. Nesse sentido, segundo Vicente (2014, p.150), “o método iconológico referese à tradução vocabular, à decifração de códigos obscuros à primeira vista, pois a familiaridade com as imagens é insuficiente para uma verdadeira análise”. Ou seja, busca interpretar os significados de uma imagem.

O método iconológico está fundamentado em três níveis de significado, a saber:

O primeiro, voltado ao significado primário ou natural, é o da descrição préiconográfica. Esta descrição consiste na identificação de formas puras, bem 
como de objetos e eventos presentes na imagem. 0 segundo nível, voltado ao significado secundário ou convencional, é o da descrição iconográfica. Diferente do nível anterior, este consiste não somente na descrição pura e simples dos objetos retratados, mas na ligação das composições da imagem com assuntos e conceitos. 0 terceiro e último nível, voltado ao significado intrínseco ou conteúdo, é denominado descrição iconológica. Esta descrição é definida pela descoberta e interpretação dos valores simbólicos presentes na imagem (PANOFSKY, 2011 apud UNFRIED, 2014, p. 3).

O primeiro nível é o nível mais básico, onde é feita uma descrição da imagem, sem qualquer contexto conceitual, mas enfatizando-se uma identificação das formas. Por sua vez, no segundo nível, além da descrição, são associadas às imagens conceitos, conhecimento e ideias elucidativas. E, por fim, no terceiro nível, recorre-se à análise subjetiva, onde se constroem relações entre obra, local, tempo e espaço com o repertório do espectador da imagem.

Nesta pesquisa utilizaram-se os três níveis para a análise das imagens, porém, optou-se por não recorrer aos expectadores dos grafites, uma vez que isto acarretaria um tempo maior na seleção e coleta das percepções dos depoentes. Além disso, vale ressaltar também que, como o segundo e o terceiro nível tratam de análises subjetivas, decidiu-se uni-los, sendo, portanto, abordados como um só.

Os grafites selecionados para análise foram produzidos durante edições do Festival Concreto - projeto idealizado, como dito anteriormente por Narcélio Grud, com o objetivo de promover uma aproximação entre a cidade e a população de modo geral. 0 festival foi adotado como objeto de análise por se caracterizar como um importante marco para o desenvolvimento da arte urbana em Fortaleza, de modo particular, e no Nordeste, de modo abrangente. Além disso, no que se refere à amostra, cabe assinalar que os grafites foram escolhidos tendo como base o acesso dos pesquisadores às imagens, todavia, privilegiando-se aquelas que permaneceram visíveis nos muros e fachadas dos prédios.

As intervenções artísticas do Festival tinham como objetivo demonstrar o papel do grafite como um agente que dá vida nova à urbe, aproximando, muitas vezes, questões e problemas locais a acontecimentos globais. Apesar do seu caráter de resistência, com a realização do Festival Concreto, o grafite passou a ser visto pelos gestores públicos como uma alternativa para embelezar a cidade. As intervenções artísticas realizadas durante as edições do evento podem ser vistas em praticamente todos os bairros da cidade. Todavia, devido à efemeridade característica do grafite, uma ou outra já pode ter sumido. 


\section{A CIDADE ENQUANTO SUPORTE DO GRAFITE}

Nesta seção, almeja-se realizar a discussão acerca dos dados coletados, apresentando os resultados obtidos através da análise de imagens.

0 mural a seguir foi produzido pelo italiano NemO's durante a $2^{\text {a }}$ ediç̧ão do Festival Concreto em 2015 e estava localizado no Centro Dragão do Mar de Arte e Cultura. Em nível primário, tem-se a imagem de um homem, uma linha de costura, um garfo e palavras. Já no nível secundário é possível identificar a frase "FOME ZERO", que entre aspas ganha o sentido de ironia, associada à imagem de um homem segurando um garfo e uma agulha. $\mathrm{O}$ homem da imagem mantém a linha presa ao garfo que utiliza para costurar a própria boca.

Figura 1 - Fome zero (NemO's).

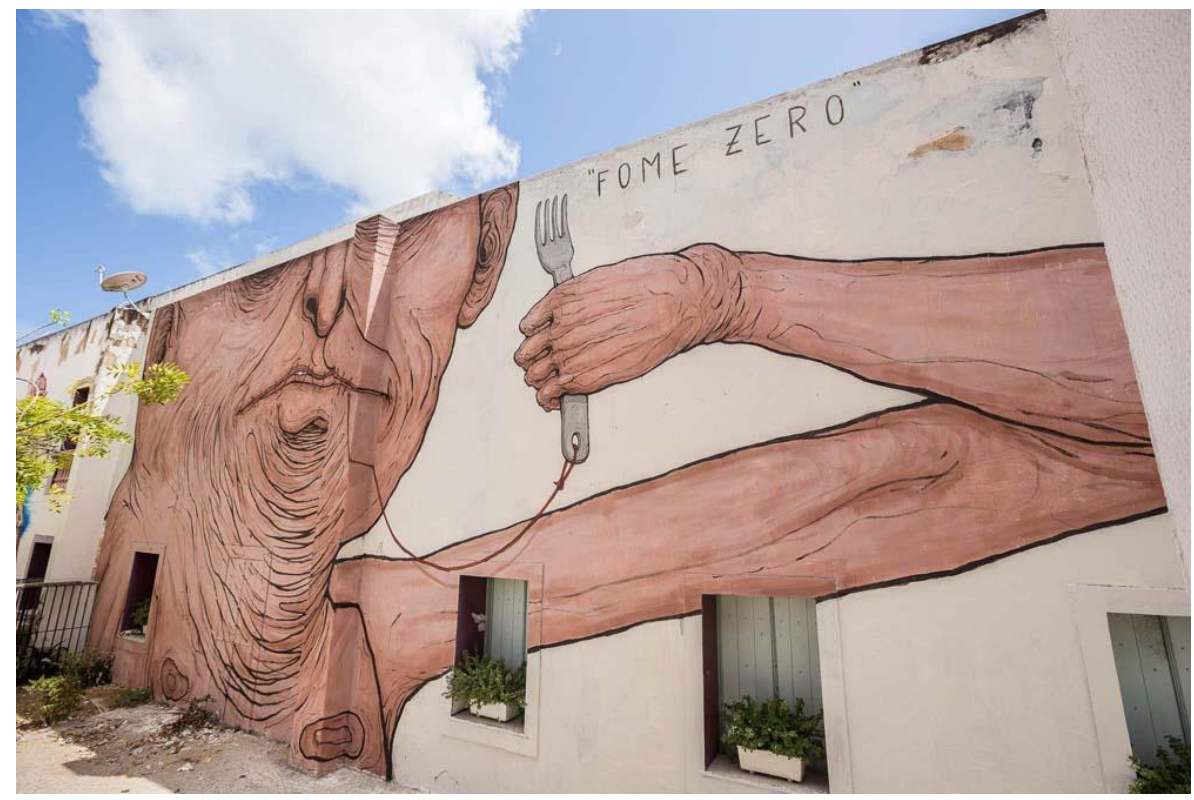

Fonte: Festival Concreto (2015).

Com base na concepção de Ramos (2007) de que o homem utiliza a informação para modificar sua realidade social, identifica-se na obra de NemO's a abertura de possíveis questionamentos acerca dos objetivos, validade e da efetividade do programa homônimo promovido pelo governo federal, que tinha como meta a erradicação da fome no Brasil. No entanto, por meio do grafite, o autor sugere a ideia de que o programa atuou apenas como um paliativo, não conferindo às populações condições mais efetivas de emancipação. 
Ainda que, neste caso, o grafite opere com um instrumento de mediação entre os indivíduos e o fato social, a construção desta reflexão depende completamente do repertório dos envolvidos (COELHO NETTO, 1980), já que o entendimento desse contexto necessita de conhecimento prévio sobre políticas públicas, em especial acerca do programa Fome Zero e do cenário social do Brasil antes e depois da execução do projeto.

Produzido pela artista argentina Hyuro, o mural a seguir também foi idealizado durante a $2^{\underline{a}}$ edição do festival Concreto. A imagem podia ser vista por quem transitava pela Rua Juvenal Galeno, tendo sido desenhada em um dos prédios da Universidade Federal do Ceará, no bairro Benfica.

Em primeiro plano, observa-se uma mulher envolta numa fita listrada, bastante comum no uso de isolamento de área. Já no segundo plano, pode-se ser levado diretamente ao significado das fitas de restrição em torno da mulher, como, por exemplo, uma mulher restringindo a si mesma, seu corpo e suas vontades ou, também, protegendo-se, impedindo a violação do seu espaço.

Figura 2 - Público/Privado (Hyuro).

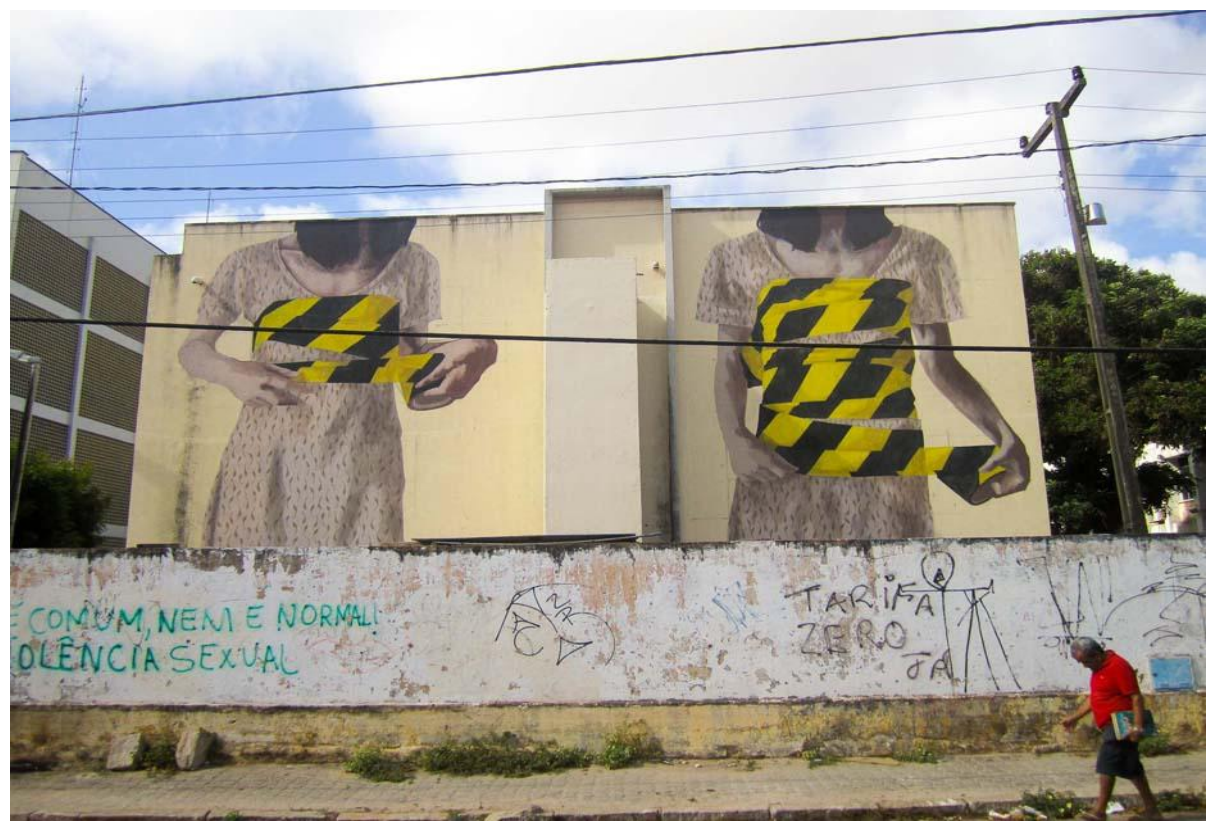

Fonte: Festival Concreto (2015).

A informação, segundo Feitosa (2016), interfere no processo de cultura e a complexidade de sua apropriação pode gerar transformações na vida do receptor. Uma das vertentes do grafite idealizado por Hyuro representa a luta do movimento feminista, que busca a igualdade entre os gêneros e traz consigo o despertar para uma reflexão 
sobre o ato de conferir maior poder à mulher e à libertação de seu corpo. Manifestos como esse se apropriam da ideia de arte engajada que, conforme Coelho Netto (1980), tem tanto poder para motivar decisões, quanto para promover mudanças efetivas em comportamentos arraigados.

O título Público/Privado complementa a obra. Embora o corpo da mulher pertença tão somente à própria mulher, diante de situações como aborto e estupro, as decisões tomadas pelo Estado brasileiro acerca de quem tem direito a interromper uma gestação se dão no âmbito da esfera pública.

Produzido pelo artista espanhol Borondo, o mural exibido a seguir, localizado no Centro Dragão do Mar de Arte e Cultura, ainda permanece colorindo as paredes do lugar. Faz-se necessário salientar que ele ainda permanece porque uma das características do grafite é sua efemeridade. Assim, idealizado durante a primeira edição do festival em 2013, o grafite Maracatu, do artista Borondo, é um das poucas inscrições que, dentre aqueles analisados aqui, mantiveram-se até os dias atuais.

Figura 3 - Maracatu (Borondo).

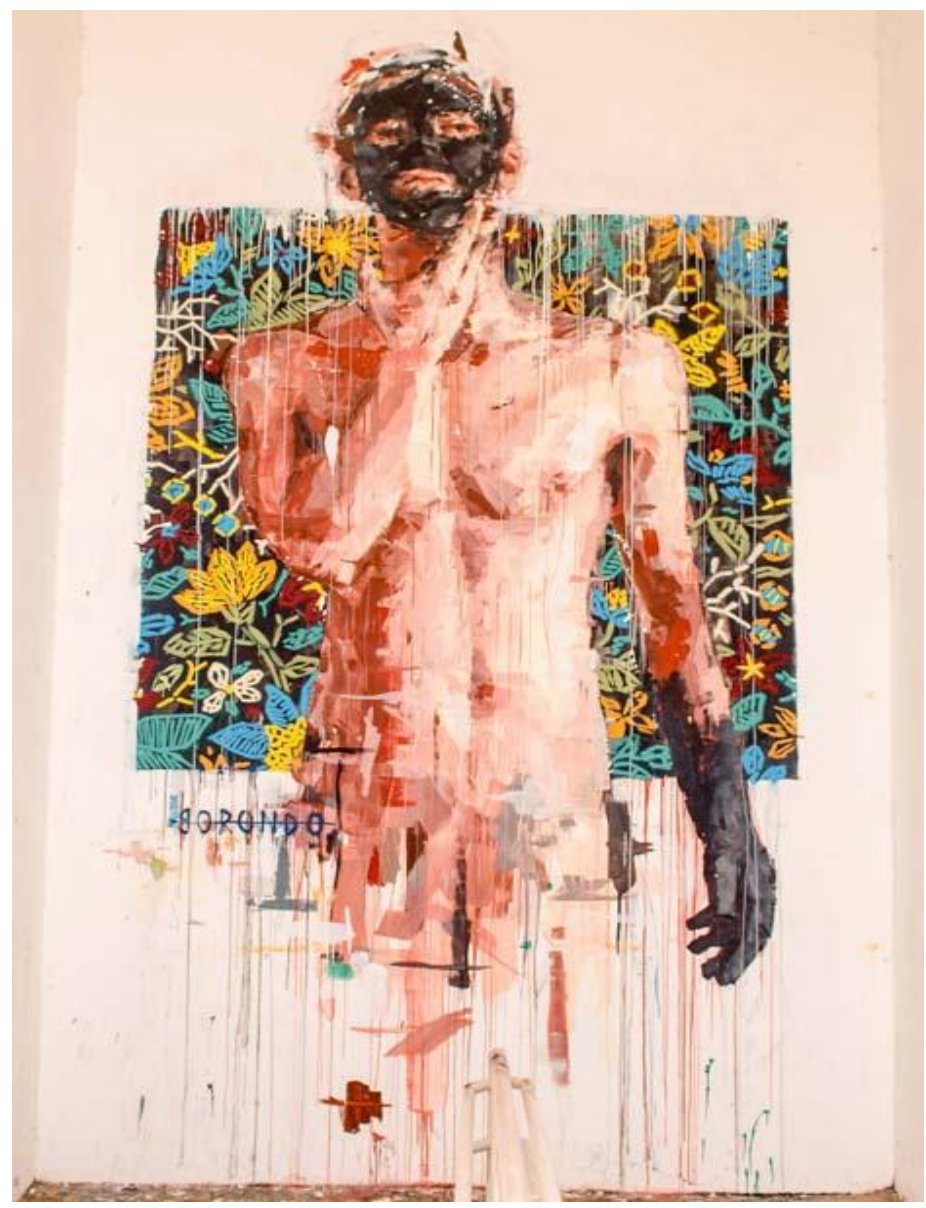

Fonte: Festival Concreto (2013). 
No primeiro nível, é possível identificar um homem de torso nu projetado à frente de um fundo florido. No próximo plano, pode-se reconhecer traços do regionalismo local, e é nele que se consegue construir uma associação entre a face pintada de preto e o colorido das flores com o Maracatu, tradição cultural da cidade de Fortaleza que conta a história de luta e resistência dos escravos negros durante a colonização.

Como discutido aqui, o início do grafite esteve ligado a movimentos de cunho político e social, como uma forma de protesto, modificando-se, contudo, em termos estéticos através da inserção de novas técnicas com o passar dos anos (RODRIGUES; BESSA, 2015). É possível compreender a obra de Borondo não como um protesto somente, mas, ainda, como a manifestação do que o artista compreendeu sobre importantes aspectos históricos da cultura local.

O desenho de Borondo vai ao encontro do que afirma Coelho Netto (1980) sobre as possibilidades de significação geradas pela informação. 0 artista se apropriou de um dos diversos elementos da cultura local e a partir dele fez leituras que deram origem a uma nova obra, que também expressa algo peculiar da cultura local. Ou seja, foi a partir de uma informação sobre elementos históricos da cultura local que Borondo conseguiu construir novos significados utilizando-se de sua arte.

Localizado no Centro de Fortaleza, entre as ruas São Paulo e Barão do Rio Branco produzido em novembro de 2015, o mural pintado pelo artista grego Ino encerrou a segunda edição do Festival Concreto e também é uma das poucas intervenções fruto do evento que ainda permanece viva na cidade de Fortaleza.

Em primeiro plano, consegue-se identificar uma criança com asas soltando um beijo sobre um globo. No segundo plano, pode-se associar o menino com as asas a um anjo, no entanto, dependendo do ângulo que a imagem é observada, as asas podem ser percebidas como chifres. Levando em consideração as circunstâncias do período de luto pela violência que a cidade se encontrava e o repertório informacional da cultura local, é provável a associação do anjo com o bem, e do demônio com o mal; com isso, pode-se interpretar que a intenção de Ino foi alertar para a existência de dois lados do mesmo garoto: o bom e o mau. 
Figura 4 - Céu e inferno na Terra (Ino).

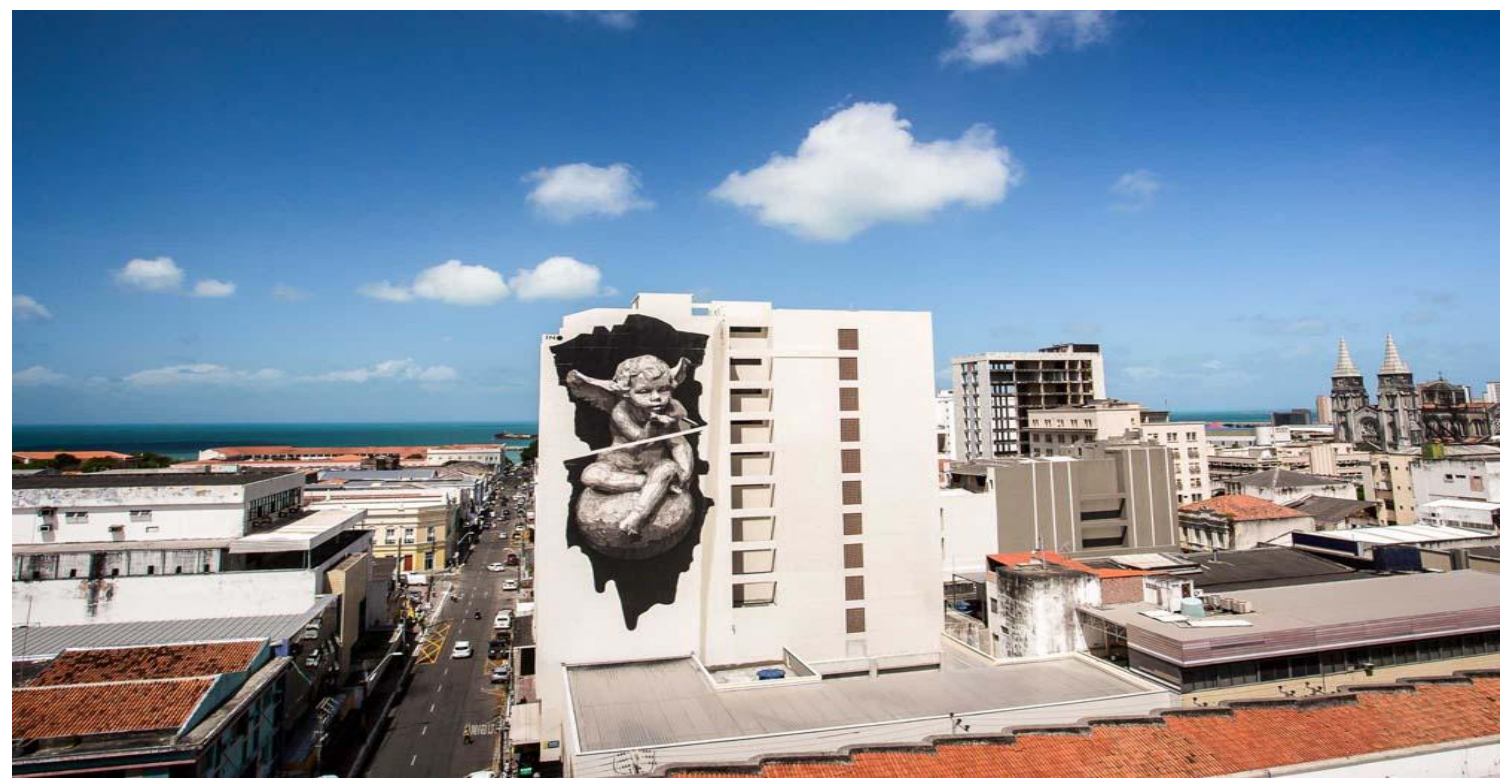

Fonte: Festival Concreto (2015).

O desenho de Ino foi concebido durante um período de medo e luto na cidade de Fortaleza, ocasionado pela tragédia conhecida como "Chacina do Curió", que se transformou em uma das maiores chacinas da história da cidade, onde um grupo de policiais é apontado nos autos do processo como sendo responsável, no ano de 2015, no bairro Curió, pela morte de sete pessoas, deixando outras três gravemente feridas, além de praticar três torturas físicas e uma psicológica - conforme informações veiculadas na matéria publicada pelo jornal 0 Povo, em 10 de novembro de 2017, após o crime ter completado dois anosiv.

A arte de Ino converge com a ideia de Furtado e Zanella (2009) de que o grafite é fruto das vivências do sujeito que o produz dentro da cidade. É importante ressaltar que a dualidade do momento vivido pelo autor pode ter impactado diretamente na sua produção, ao mesmo tempo em que participava de uma celebração à arte urbana, o artista testemunhou uma cidade que ainda chorava pela perda dos seus jovens e questionava as motivações de um crime cruel.

Em 2017, o artista voltou a Fortaleza a fim de contribuir em mais uma edição do Festival Concreto, abordando a mesma temática e traduzindo seu olhar sobre a cidade através da arte mais uma vez. 0 mural a seguir foi elaborado também por Ino, porém foi inscrito durante a $4^{\mathrm{a}}$ edição do Concreto e está localizado no Hotel Sonata de Iracema, entre as avenidas Beira Mar e a Historiador Raimundo Girão, no Bairro Praia de Iracema. 
Em primeiro nível, dá para se apontar a existência de um corpo feminino nu sob um fundo preto. Já em segundo nível, é possível enxergar um corpo sofrido, magro e, ainda assim, exprimindo uma conotação sexual. Fortaleza é conhecida pelo significativo número de casos envolvendo prostituição, exploração e turismo sexual, principalmente nas proximidades do local onde o desenho foi realizado. São dois lados de uma mesma cidade, uma contradição onde o mesmo lugar que abriga belas praias e hotéis de luxo também é lugar de pobreza e exploração sexual.

Figura 5 - Broken (Ino).

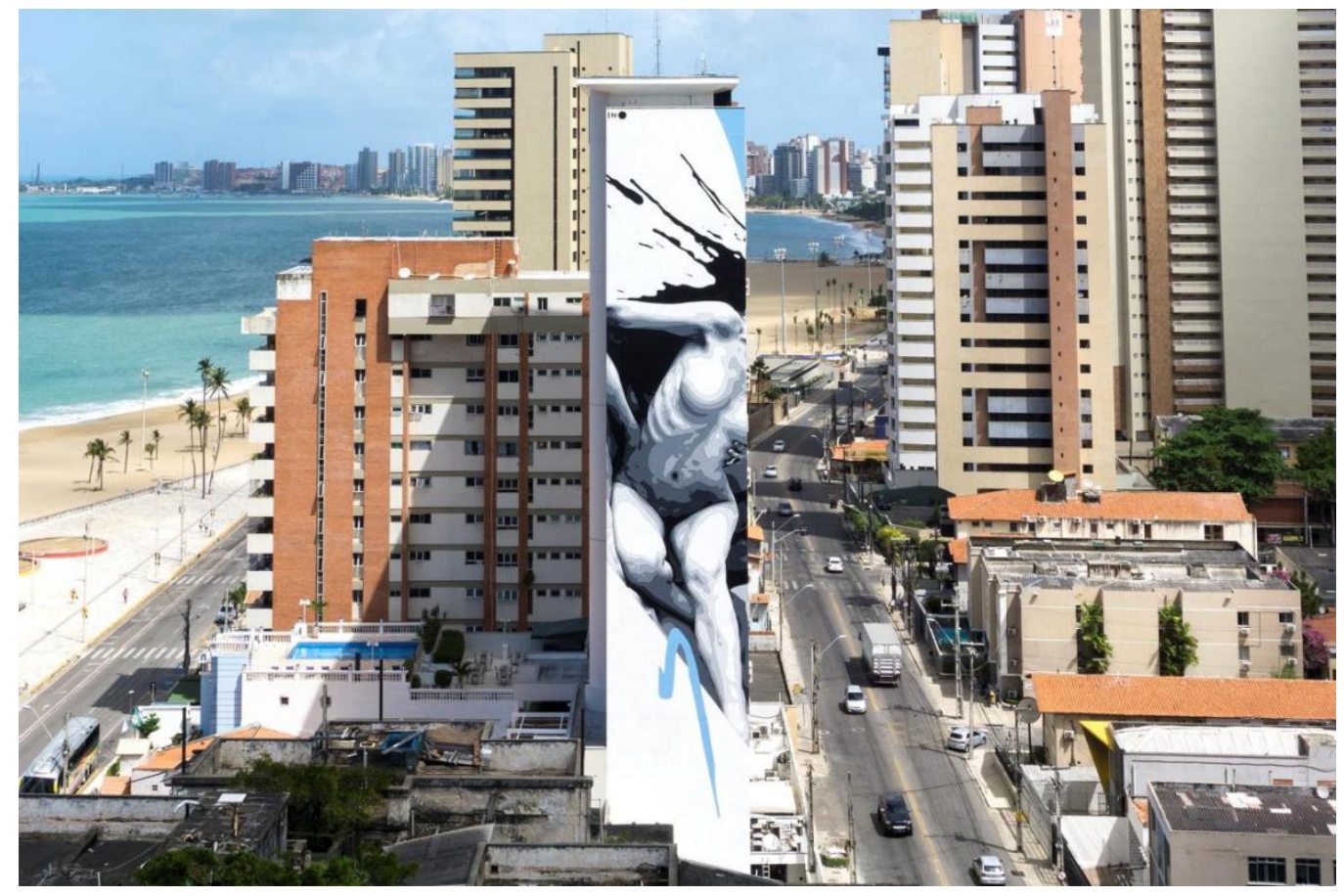

Fonte: Street Art News (2017).

As obras representam bem o objetivo por trás da criação do Festival Concreto e da arte urbana de modo geral. Durante a discussão sobre a história do grafite, Gitahy (1999), Ramos (2007), Furtado e Zanella (2009) e Grud (2013) ao falar da criação do Festival, ressaltam a importância da arte urbana para a construção de uma memória coletiva e para provocar o debate e a conscientização sobre a vida em seus diferentes aspectos. Assim, foi buscando justamente essa conscientização que o artista Ino produziu suas obras para o Festival.

Em um mesmo desenho pode ser visto tanto um garoto pensativo, retratado pelas mãos de um talentoso artista, quanto é possível, também, a construção de diferentes sentidos para a imagem, provocando uma sensibilização acerca da realidade 
de crianças que são vistas como diferentes, seja pela aparência em si ou pela condição física ou mental. É durante esse aprofundamento que a imagem ganha um novo significado. 0 garoto passa a ser ícone de uma causa, enquanto empina o que dá para imaginar ser uma pipa, simbolizando esperança e força.

O grafite a seguir compreendeu parte da $3^{\circ}$ edição do Festival Concreto, produzido pelo brasileiro Dinho Bento. 0 mural estava localizado no viaduto do cruzamento das Avenidas Rui Barbosa e General Murilo Borges, no Bairro Aerolândia, em Fortaleza.

No primeiro plano, identifica-se a presença de um pássaro com a cabeça de um homem barbudo, próximo a um ninho de passarinhos. Além disso, vê-se, também, lama, carcaças de animais mortos, casas e uma cruz. No plano seguinte, pode-se compreender que o mural retrata um cenário de devastação, onde todos os elementos, com exceção do pássaro com cabeça de homem, que aparenta estar migrando junto de sua ninhada, estão encobertos por um mar de lama.

Figura 6 - Verde lama (Dinho Bento).

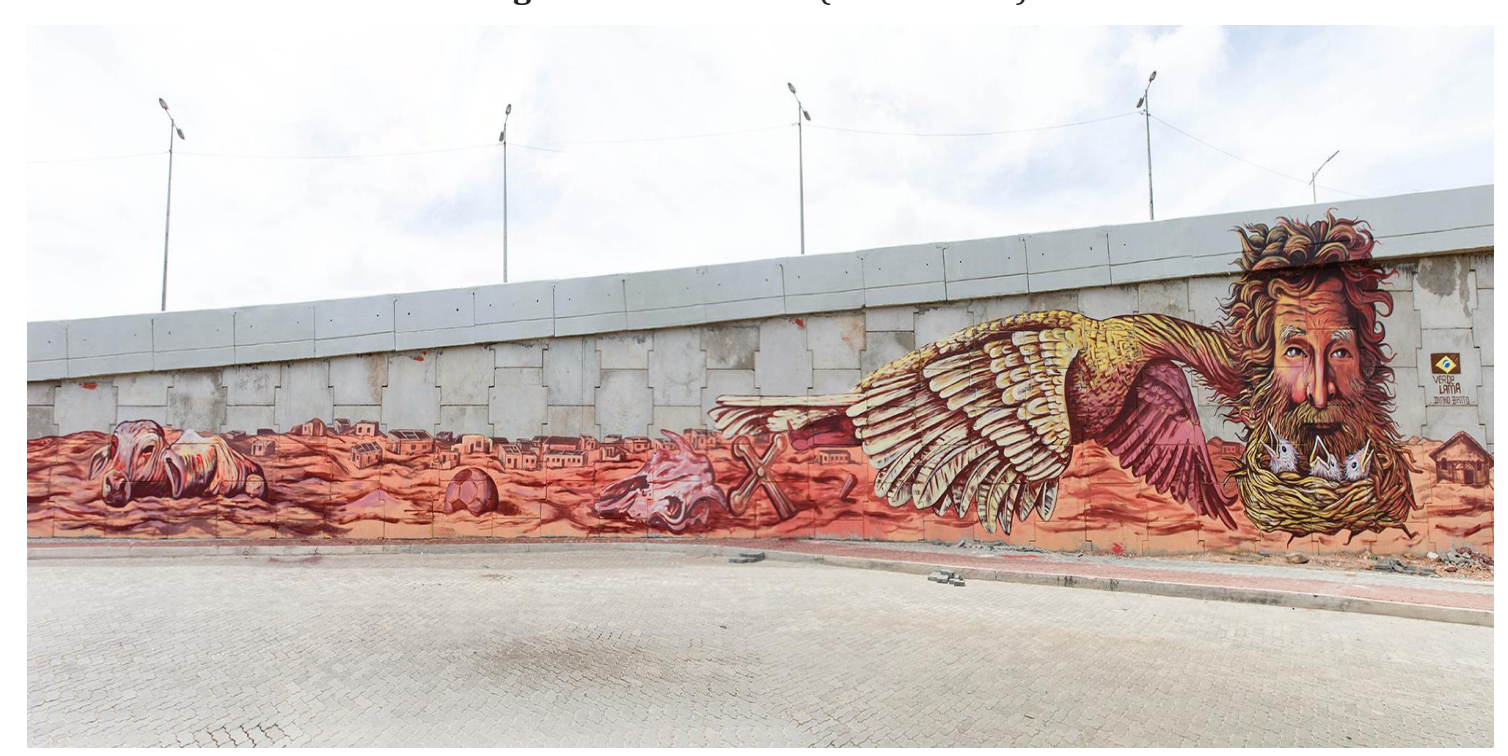

Fonte: Flickr [200-?].

Analisando esta imagem, faz-se necessário levar em consideração as raízes do artista que produziu o grafite. Dinho Bento é mineiro e cresceu em Mariana, cidade que ficou conhecida pela maior tragédia ambiental registrada no Brasil, ocorrida em novembro de 2015, exatamente um ano antes da sua participação no Festival Concreto. 
Em decorrência do rompimento de uma barragem em um distrito próximo, a lama e os rejeitos provenientes da extração de minério invadiram a cidade de Mariana, arrastando consigo casas, igrejas, prédios comerciais, pessoas e muitas das coisas que faziam parte da história do autor da obra, que, agora, infelizmente, confunde-se com a história da cidade que está submersa em lama. 0 fato foi noticiado em vários veículos de comunicação à época, tendo cobertura, inclusive, pela mídia internacional, dentre as quais, vale citar a série produzida pelo El País ${ }^{v}$.

A cidade não representa apenas o recorte físico de um espaço, mas, sim, um locus, onde os homens encontram meios de significar suas vivências. Foi dessa forma que Dinho encontrou uma maneira de representar algo significativo para si, ao mesmo tempo em que se utilizou do poder do grafite e de sua capacidade de representar algo capaz de instigar questionamentos e manifestar-se de maneira crítica acerca de valores, ideias ou mesmo sobre a ocupação da urbe.

É importante ressaltar que toda essa análise sobre o grafite só é possível se o público tiver conhecimento sobre a tragédia, ou seja, a leitura a ser feita de uma imagem ou dos textos contidos na inscrição depende do repertório de conhecimentos e saberes do artista e do receptor. Trata-se, portanto, de uma ação socialmente contextualizada e simbolicamente situada.

\section{CONCLUSÃO}

As discussões sobre o grafite suscitam inúmeras questões quanto ao seu papel na sociedade atual. 0 grafite sempre teve em sua essência a crítica, mas ao longo dos anos ele vem ganhando cada vez mais espaço como um instrumento de arte e manifestação cultural.

Ao abordar o grafite como um meio de mediação cultural e uma fonte de informação estética, agregam-se novos valores para uma arte que nasceu marginalizada, porém, que, aos poucos, foi ganhando espaço em galerias de arte e campanhas publicitárias, atuando, inclusive, como instrumento de requalificação do espaço urbano, desconstruindo, também, o clichê de que algo ruim ou puramente poluição visual.

Os grafites produzidos no Festival Concreto demonstram que muito mais do que apenas agente embelezador, as pinturas produzidas buscam despertar conscientização 
sobre problemas sociais e mostrar essa expressão da arte urbana como instrumento de mediação e transformações da cultura local.

Ao utilizar-se da cidade como principal suporte, o grafite, que nasceu de uma cultura marginal e tem como uma de suas principais características a efemeridade, pode ser hoje abordado como uma importante forma de democratização da arte e mediação cultural nas cidades. A análise dos grafites do Festival Concreto possibilitou, portanto, observá-lo sob uma nova ótica, como uma manifestação artística que não traz apenas beleza pra cidade, mas que tem possibilidades de impulsionar mudanças na cultura, na memória e na sociedade de modo geral.

\section{REFERÊNCIAS}

ALBUQUERQUE, Ana Cristina de. 0 grafite como canal alternativo de informações: caminhos para uma discussão interdisciplinar em Ciência da Informação. Revista de iniciação científica da FFC. Marília, ano 3, v. 4, 2004.

ALMEIDA JÚNIOR, Oswaldo Francisco de. Mediação da informação e múltiplas linguagens. Tendências da Pesquisa Brasileira em Ciência da Informação, Brasília, v. 2, n. 1, p. 89-103, jan./dez. 2009. COELHO NETTO, J. Teixeira. Semiótica, informação e comunicação. São Paulo: Perspectiva, 1980.

DAVALLON, Jean. A mediação: a comunicação em processo? Prisma.com, Porto, n. 4, 2007.

FEITOSA, Luiz Tadeu. Complexas mediações: transdisciplinaridade e incertezas nas recepções informacionais. Informação em pauta, Fortaleza, v. 1, n. 1, jan./jun., 2016.

FURTADO, Janaina Rocha; ZANELLA, Andréa Vieira. Graffiti e cidade: sentidos da intervenção urbana e o processo de constituição dos sujeitos. Revista mal-estar e subjetividade, Fortaleza, v. 9, n. 4, p. 12791302, dez. 2009.

GITAHY, Celso. 0 que é graffiti. São Paulo: Brasiliense, 1999.
LARAIA, Roque de Barros. Cultura: um conceito antropológico. Rio de Janeiro: Zahar, 2001.

MINAYO, Maria Cecília de Souza (Org.).

Pesquisa Social: Teoria, método e criatividade. Petrópolis: Vozes, 2001.

NUNES, Jefferson Veras; CAVALCANTE, Lidia Eugênia. Por uma epistéme mediacional na Ciência da Informação. Anais... XVIII Encontro Nacional de Pesquisa em Ciência da Informação, Marília, SP, 2017. Marília, SP: Associação Nacional de Pesquisa e PósGraduação em Ciência da Informação, 2017.

PEREIRA, Aleksandra Previtalli Furquim. 0 Benfica dos grafites nos anos 2000. 2012. 215f. Dissertação (Mestrado) - Programa de Pós-graduação em Educação Brasileira, Universidade Federal do Ceará, Fortaleza, 2012.

PERROTTI, Edmir. Mediação cultural: além dos procedimentos. In: SALCEDO, D. A. (Org). Mediação cultural. São Carlos: Pedro \& João Editores, 2016.

RAMOS, Luciene Borges. 0 centro cultural como equipamento disseminador de informação: um estudo sobre a ação do Galpão Cine Horto. 2007. 243 f. Dissertação (Mestrado em Ciência da Informação) - 
Escola de Ciência da Informação, Universidade Federal de Minas Gerais, Belo Horizonte, 2007.

RODRIGUES, Kadma Marques; BESSA, Nicole Sousa. 0 grafite em Fortaleza. Tensões Mundiais, Fortaleza, v. 11, n. 20, p. 209-236, 2015.

SANTOS, José Luiz dos Santos. 0 que é cultura. São Paulo: Brasiliense, 1996.
UNFRIED, Rosana Aparecida Reineri. 0 uso da iconografia e da iconologia para a análise de fotografias e recuperação da história de Londrina. In: Encontro Nacional de Pesquisa em Comunicação e Imagem - ENCOI, 2014, Londrina. Anais... Londrina: UEL, 2014.

VICENTE, Tania Aparecida de Souza. Metodologia da análise de imagens. Revista Contracampo, Niterói, n. 4, jan. 2000.

\section{NOTAS}

\footnotetext{
i Texto extraído do site: Festival Concreto. Disponível em: http://www.festivalconcreto.com.br/festival/edicao2013. Acesso em: 31 mar. 2018.

ii Texto extraído do site: Festival Concreto. Disponível em: http://www.festivalconcreto.com.br/festival. Acesso em: 31 mar. 2018 iii Texto extraído do site: Festival Concreto. Disponível em: http://www.festivalconcreto.com.br/festival/. Acesso em: 31 mar. 2018. iv Informação extraída de: https://www.opovo.com.br/jornal/cotidiano/2017/11/dois-anos-depois-chacina-da-grande-messejanaesta-longe-do-desfecho.html. Acesso em: 16 nov. 2018.

v Disponível em: https://brasil.elpais.com/tag/mariana/b. Acesso em: 16 nov. 2018.
} 